\title{
Impact of wastewater on nitrate concentrations in soil and vegetables grown along Kubanni River, Zaria in Kaduna State, Nigeria
}

\author{
S.O. Oladeji \\ Department of Polymer Technology, Hussaini Adamu Federal Polytechnic, Kazaure, Jigawa State, NIGERIA \\ E-mail: saheedilori75@gmail.com
}

\section{ARTICLE HISTORY}

Received: 24 October 2017

Revised received: 05 November 2017

Accepted: 15 November 2017

\section{Keywords}

Analysis of variance

Kubanni River

Nitrate levels

Pearson product moment correlation Vegetable

Wastewater

\begin{abstract}
The concentration of nitrate was evaluated in wastewater, soil and vegetable (carrot, lettuce, onion, spinach, cabbage, tomato and okra) samples collected on seasonal basis from January, 2013 to September 2014 along Kubanni stream channels in Zaria. The results showed nitrate levels in wastewater were in the range of $23.05-283.54 \mathrm{mg} / \mathrm{L}$ for the year 2013 and $16.85-68.05 \mathrm{mg} / \mathrm{L}$ in the year 2014; soil had concentrations in the range of $2.20-20.50 \mathrm{mg} / \mathrm{kg}$ for 2013 and $7.27-29.57 \mathrm{mg} / \mathrm{kg}$ for the second year while the vegetable had concentrations in the range of $3.80-23.65 \mathrm{mg} / \mathrm{Kg}$ for the year 2013 and 7.48-27.15 mg/Kg in year 2014. Statistical analysis revealed no significant difference in nitrate concentrations across the locations and seasons for wastewater, soil and vegetables analyzed. Pearson correlation results revealed negative $(r=-0.263)$ relationship between nitrate levels in wastewater for year 2013 and year 2014, likewise negative $(r=-0.217)$ relationship was obtained for vegetables planted in the year 2013 and 2014 whereas negligible $(r=0.137)$ relationship was recorded in the soil for these years. Nitrate concentrations obtained in this study was higher than maximum contaminant levels set by Standard Organization such as WHO and FAO for wastewater whereas the soil and vegetable of the sampling sites were not contaminated with nitrate ions.
\end{abstract}

(C)2017 Agriculture and Environmental Science Academy

Citation of this article: Oladeji, S.O. (2017). Impact of wastewater on nitrate concentrations in soil and vegetables grown along Kubanni River, Zaria in Kaduna State, Nigeria. Archives of Agriculture and Environmental Science, 2(4): 318-324, DOI: 10.26832/24566632.2017.020413

\section{INTRODUCTION}

Wastewater is described as combination of the liquid or water-carried from residences, institutions, commercial and industrial establishments together with groundwater and surface water which has been adversely affected by anthropogenic influences (Morrison et al., 2001; Kumar et al., 2017; Oladeji, 2017). When untreated wastewater accumulates and is allowed to get septic, the decomposition of the organic matter it contains will lead to nuisance conditions which include the generation of offensive gases/odour. In addition, untreated wastewater contains numerous pathogenic microorganisms that dwell in it and if such water is drunk it may get to human intestinal tract and cause sickness (Ademoroti, 1996). Quality of wastewater depends on its sources i.e. sewage or industrial effluents (Akan et al., 2010; Kumar et al., 2017). Wastewater can contain pollutants such as organisms, pathogens, organic matter, oil, grease, inorganic, nutrients, solids and gases in large quantity that can put public at health risk and the environment in general (Agusa et al., 2006; Jameel and Sirajudden, 2006; Oladeji, 2017). Wastewater contains nutrients which stimulate the growth of planktons in aquatic environment and may contain toxic compounds or compounds that potentially may be mutagenic or carcinogenic. For these reasons, the immediate and nuisance-free removal of wastewater from its sources of generation, followed by treatment, reuse, or dispersal into the environment is necessary to protect public health and the environment (Tchobanoglous et al., 2003; Oladeji, 2017). To protect public health and the environment, it is necessary to have knowledge of constituents of concern wastewater, impacts of these constituents of wastewater when it disposed untreated into the environment, the transformation and long-term fate of the constituents if left untreated, treatment processes it requires and treatment/ methods that can be used to remove or modify the constituents found in wastewater (Berman, 1980; Oladeji, 2017).

Nitrate $\left(\mathrm{NO}_{3}{ }^{-}\right)$is inorganic ions that occur naturally and are part of the nitrogen cycle. Nitrates (e.g., potassium nitrate and ammonium nitrate) are common ingredients of fertilizer that contains nitrogen. Nitrite oxidizes easily into nitrate by Nitrobacter. Thus, nitrate occurs more frequently in ground and surface water. Nitrate-containing compounds in the soil are generally soluble that means they dissolve easily in water (ATSDR, 2011). Thus, nitrates flow easily into groundwater. Microbes break down animal and human organic wastes in soil and water to ammonia. This breakdown process of converting organic wastes into ammonia, which then oxidizes into nitrite and nitrate, is referred to as Nitrification process done by Nitrosomonas and Nitrobacter bacteria (Grubben, 1976). Vegetables such as cauliflower, spinach, collard greens, broccoli, beets and root vegetables are having greater nitrate content than do other plants due to nitrogen fixation and is one way of exposing to excessive nitrite and nitrate in 
foods (ATSDR, 2011). Also, exposure to high amounts of nitrates/nitrites from soil and water contaminated arise from runoff of nitrogen-containing fertilizers (e.g., potassium nitrate and ammonium nitrate) as being reported in literatures (Akan et al., 2010). Excessive nitrate exposures by people resulted in acute methemoglobinemia, a serious health condition. Haemoglobin in blood carries oxygen from the lungs to tissues and helps carry carbon dioxide back to the lungs. Haemoglobin in blood contains iron normally found in the $\mathrm{Fe}^{2+}$ (ferrous) state. An excessive nitrate alters the iron in haemoglobin to the $\mathrm{Fe}^{3+}$ (ferric) state. This forms methemoglobin, an abnormal form of haemoglobin. As methemoglobin forms, the blood loses its ability to carry oxygen to tissues (anoxia). Methemoglobinemia is a state in which there is an excess of methemoglobin in the blood. Methemoglobinemia can cause cyanosis (blue skin) of limbs/trunk, weakness and rapid heart rate (ATSDR, 2011). If methemoglobinemia progresses in severity, central nervous system depression can occur this may result to headache, dizziness, fatigue, difficulty in breathing and nausea (Nathan et al., 1977). Finally, severe methemoglobinemia can cause lethargy, brief loss of consciousness, irregular heartbeat, shock, convulsions, coma, and even death. In fact, methemoglobin levels greater than $50 \%$ are potentially fatal (Reddy and Menary, 1990). Keeping above in view, the present investigation was aimed to evaluate the levels of nitrate in wastewater, soil and vegetable samples grown along Kubanni stream channels in Zaria, Kaduna State, Nigeria.

\section{MATERIALS AND METHODS}

Sampling: Wastewater samples from Kubanni stream were obtained on a four-month basis at point of inlet into the river at five different points along the stream channels for the period of two years. Sampling was conducted in the Harmattan, dry and rainy seasons from January 2013 to September 2014. Wastewater samples were collected using composite sampling in a polyethylene plastic containers that were previously cleaned by washing in non-ionic detergent, rinsed with tap water and soaked in $0.1 \mathrm{M} \mathrm{HNO}_{3}$ for 24 hours and finally rinsed with deionized water prior to usage (Ademoroti, 1996). Sample bottles used were rinsed with sampled water three times and then filled to the brim at a depth of one meter below the wastewater from each of the five designated sampling points. Wastewater sample bottles were labeled, stored in ice-blocked coolers and transported to the laboratory while in the Analytical laboratory; they were stored in the refrigerator at about $4{ }^{\circ} \mathrm{C}$ prior to the analysis (APHA, 2012). Soil samples were collected at three depths $(0-5 \mathrm{~cm}, 5-10 \mathrm{~cm}$ and 10-15 $\mathrm{cm})$ from both sides of the river banks by using spiral auger of $2.5 \mathrm{~cm}$ diameter. Soil samples were randomly sampled and bulked together to form a composite sample from each designated point. They were then put in clean plastic bags, labelled and transported to the laboratory. The full grown vegetable of spinach (Amaranthus hybridus), lettuce (Lactuca sativa), cabbage (Brassica oleracea), carrot (Daucus carota), okra (Hibiscus esculentus), onion (Allium cepa) and tomato (Lycopersicon esculenetum) were randomly handpicked from various garden plots along Kubanni stream channels using hand-gloves, bulked together to form a composite sample, wrapped in a big brown envelopes, labeled accordingly and transported to the laboratory.

Sample treatment: Wastewater sample bottles were kept in a refrigerator set at $4{ }^{\circ} \mathrm{C}$ prior to analysis (APHA, 2012). Soil samples were air-dried, crushed and sieved through $2 \mathrm{~mm}$ mesh sieve. The soil samples were then put in clean plastic bags, sealed and labelled accordingly (Musa et al., 2009). Each vegetable samples were washed with tap water, followed by deionized water, air dried in the laboratory, grounded to powder and sieved using $250 \mu \mathrm{m}$ sieve (Munson and Nelson, 1990).

Determination of nitrate in wastewater: $10 \mathrm{~cm}^{3}$ of the each wastewater samples were pipetted into sample containers. The content of one (NitraVer 5 Nitrate) reagent powder pillow was added to each wastewater samples. It was stoppered and the cell shaken thoroughly for 1 minute. The sample concentration was read for each wastewater at $500 \mathrm{~nm}$ after 5 minute using a portable Data Logging Spectrophotometer (HACH $\mathrm{DR} / 2010)$. The blank sample was treated in the same manner. The result in $\mathrm{mg} / \mathrm{L}$ nitrate-nitrogen $\left(\mathrm{NO}_{3}{ }^{-} \mathrm{N}\right)$ was displayed. It was multiplied by a conversion factor of 4.427 to get the nitrate concentration (APHA, 2012).

Determination of nitrate in soil samples: The concentration of the chloride in the soil samples filtrates were firstly determined, the readings of chloride were divided by 10 and known amount of $0.02 \mathrm{M} \mathrm{Ag} \mathrm{SO}_{4}$ were added equivalent to the amount of chloride in the filtrates. $5 \mathrm{~cm}^{3}$ aliquots were then taken into centrifuge test tube and diluted to $10 \mathrm{~cm}^{3}$ with deionized water. The tubes were centrifuged for 10 minutes until the solutions were clear. $5 \mathrm{~cm}^{3}$ of the clear solutions were taken in glass evaporating dish, placed on water bath, evaporated to dryness and then cooled. $1 \mathrm{~cm}^{3}$ of phenoldisulphonic acid solution was added to individual tubes, then $10 \mathrm{~cm}^{3}$ of deionized waters were added and were transferred into various $100 \mathrm{~cm}^{3}$ volumetric flasks and were made alkaline by adding $2 \mathrm{~cm}^{3}$ of concentrated $\mathrm{NH}_{4} \mathrm{OH}$, diluted to volumes of 50 $\mathrm{cm}^{3}$ and thoroughly mixed to give a yellow colour and their absorbance were taken at $410 \mathrm{~nm}$ using JENA Model UV/ Visible Spectrophotometer for nitrate. The blank was prepared by following the same procedure while omitting the filtrate used for the analysis (Musa et al., 2009).

Determination of nitrate in the vegetable samples: The concentration of nitrate and nitrite analyzed in each of the vegetable samples were carried out using Smart Spectro spectrophotometer (APHA, 2012). The method is based on diazotization of sulphanilic acid by nitrite in acid solution and the coupling of the resulting diazonium compound with alphanaphthyl-amine to give a red azo-dye (Ademoroti, 1996). Vegetable samples solutions were prepared by grinding each dried sample into powder. A known amount $(1 \mathrm{~g})$ of the powdered sample was transferred into $100 \mathrm{~cm}^{3}$ flask and soaked with $50 \mathrm{~cm}^{3}$ of deionized water. The flasks were capped and shaken for 30 minutes, then filtered into another $100 \mathrm{~cm}^{3}$ volumetric flasks and the volume made to the mark with deionized water. Nitrate was determined spectrophotometrically using standard cadmium reduction method (Radojevic and Bashkin, 1999). $25 \mathrm{~cm}^{3}$ of the filtrate that had been previously mixed with $50 \mathrm{~cm}^{3}$ of $\mathrm{NH}_{4} \mathrm{Cl}$-EDTA solutions were passed through cadmium column and collected at a rate of 10 $\mathrm{cm}^{3} /$ minute. $2 \mathrm{~cm}^{3}$ of sulfanilamide reagent was then added to $50 \mathrm{~cm}^{3}$ of collected filtrate from column for colour development and was allowed to react for 5 minute with $2 \mathrm{~cm}^{3}$ of naphthyl-ethylenediamine dihydrochloric acid with the formation of reddish purple azo dye and the absorbance of the solution was then taken at $540 \mathrm{~nm}$ (Kenneth, 1990).

Statistical analysis: The results of nitrate in wastewater, soil and vegetables analyzed were expressed in form of bar-charts. The results obtained were subjected to one way 
Analysis of Variances (ANOVA) and Pearson Product Moment Correlations (PPMC) using Statistical Package for the Social Sciences (SPSS) 20.0 version software. Null hypothesis was adopted and this was set at $95 \%$ confidence mean level to check if there is significant difference in the concentrations of nitrate analyzed. Statistical decision for Pearson correlation coefficients ( $r$ ) were in accordance to Robert (1992).

\section{RESULTS AND DISCUSSION}

The results of nitrate concentrations in wastewater from Kubanni stream channels is shown in Figure 1. The concentrations determined were in the range of $23.05-283.54 \mathrm{mg} / \mathrm{L}$ for the year 2013. Highest level of $283.54 \mathrm{mg} / \mathrm{L}$ was found at Industrial area along Jos road followed by Unguwa-fulani $(242.75 \mathrm{mg} / \mathrm{L})$ and this was closely followed by $207.93 \mathrm{mg} / \mathrm{L}$ at Kwangila sampling site, all these results were obtained in the rainy season whereas the least level of $23.05 \mathrm{mg} / \mathrm{L}$ was obtained at Sabon-gari in the dry season. High levels of nitrate during the rainy season could be related to indiscriminate disposal of animal and human faeces from nearby houses into sampling sites coupled with fertilizer runoff from agricultural farmland as suggested by Ikemoto et al. (2002). Other sites with high concentrations of nitrate were; Sabongari $(197.60 \mathrm{mg} / \mathrm{L})$ during the rainy season, Tundun-wada $(158.42 \mathrm{mg} / \mathrm{L})$ in the rainy season, Industrial-area along Jos road $(152.48 \mathrm{mg} / \mathrm{L})$ during harmattan season, Unguwa-fulani had nitrate level of $150.43 \mathrm{mg} / \mathrm{L}$ in the harmattan season while Tundun-wada showed of $142.75 \mathrm{mg} / \mathrm{L}$. Elevated levels of nitrate noticed during the rainy season (158.42$283.54 \mathrm{mg} / \mathrm{L}$ ) could be related to animal and human faeces from nearby houses as suggested by Ishiwata et al. (2002). The concentrations determined for nitrate in the year 2014 were in the range of $16.85-68.05 \mathrm{mg} / \mathrm{L}$. Sabon-gari indicated highest level of $68.05 \mathrm{mg} / \mathrm{L}$ during the dry season followed by $43.75 \mathrm{mg} / \mathrm{L}$ at Unguwa-fulani also in the dry season and this was closely followed by $41.80 \mathrm{mg} / \mathrm{L}$ at the same sampling site but in the rainy season whereas the least level of $16.85 \mathrm{mg} / \mathrm{L}$ was recorded during harmattan season at Tundun-wada sampling site. High levels of nitrate during dry and rainy seasons could be as a result of runoff from fertilizers application on farmland as suggested by McCall and Willumsen (1998). Other sites with high concentrations of nitrate were; Kwangila $(35.80 \mathrm{mg} / \mathrm{L})$ in the rainy season, Tundun-wada $(38.19 \mathrm{mg} / \mathrm{L})$ and Industrial-area along Jos road $(35.43 \mathrm{mg} / \mathrm{L})$ both in the dry season. Low levels of nitrate was noticed in 2014 and this indicates maximum uptake of nitrate by planted vegetables as suggested by Anjana et al. (2006). Comparing the results obtained in the year 2013 and 2014, it was revealed that in harmattan season 2013, the results indicated higher concentration of nitrate ions $(114.00-200.07 \mathrm{mg} / \mathrm{L})$ than harmattan season of 2014 (16.85-34.24 mg/L). Likewise, dry season 2013 showed high level of nitrate $(23.05-200.07 \mathrm{mg} / \mathrm{L})$ than dry season 2013 (29.64-68.05 $\mathrm{mg} / \mathrm{L})$ and in the same way, rainy season of 2013 indicated high concentration of nitrate ion (158.42$283.54 \mathrm{mg} / \mathrm{L})$ than rainy season of 2014 (27.40-41.80 mg/L). High levels of nitrate recorded in 2013 could be as a result of excessive application of manure and nitrogenous fertilizers on farmlands more than required by the vegetables as suggested by Ikemoto et al. (2002). WHO recommends 45 $\mathrm{mg} / \mathrm{L}$ as maximum limit for nitrate in wastewater before it could be discharged into surface water and this indicates that concentrations obtained in this study exceeds the limit with exception of rainy season 2014 (27.40-41.80 mg/L). Akan et al. (2008) reported $211.43-284.33 \mathrm{mg} / \mathrm{L}$ as nitrate levels in wastewater which was higher than concentrations obtained in this present study. Analysis of variance was conducted to establish difference in nitrate levels among the sampling locations for the year 2013 and 2014.

Statistical analysis showed their mean with standard deviation as thus; Kwangila (88.977 \pm 74.510$)$, Unguwa-fulani

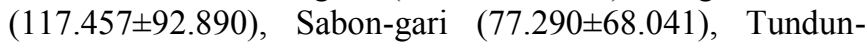
wada $(77.108 \pm 59.923)$ and Industrial-area along Jos road (98.083 \pm 90.077$)$, respectively. From ANOVA Table 1 below, it shows $\mathrm{P}=0.902>0.050$ this means that there is no significant difference in nitrate levels across the sampling locations. Nitrate concentrations were also examined across the seasons to establish their differences. Their mean with standard deviation showed these; harmattan season 2013

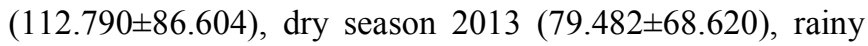
season 2013 (108.184 \pm 103.227$)$, harmattan season 2014 (57.196 \pm 49.864$)$, dry season $2014(97.660 \pm 79.452)$ and rainy season $2014(95.386 \pm 91.805)$, respectively. Table 1 reveals $\mathrm{P}$ $=0.899>0.050$ this means that there is no significant difference in nitrate concentrations across the seasons. This might be due to sampling areas are falling within the same vicinity thereby their soil geological formations are similar irrespective of change in seasons as suggested by Farooq et al. (2008). Pearson Product Moment Correlation (PPMC) was conducted to establish the relationship between nitrate levels in wastewater for the year 2013 and 2014 as shown in Table 2. Statistical analysis showed that the mean with standard deviation level for nitrate to be $149.457 \pm 70.238$ in 2013 while $34.109 \pm 12.071$ was obtained in 2014. Statistical analysis also indicates Pearson correlation $(r)=-0.263$, degree of freedom $(\mathrm{df})=13$ and $\mathrm{P}=0.343>0.050$ this means that there is negative relationship between nitrate levels in wastewater for the year 2013 and 2014, respectively.

Figure 2 presents nitrate concentrations in soil from Kubanni stream channels. The concentrations obtained were in the range of $2.20-20.50 \mathrm{mg} / \mathrm{Kg}$ for the year 2013 . Highest level of $20.50 \mathrm{mg} / \mathrm{Kg}$ was found at Kwangila sampling site during the harmattan season followed by $17.90 \mathrm{mg} / \mathrm{Kg}$ in the dry season at Sabon-gari and closely followed by $14.45 \mathrm{mg} / \mathrm{Kg}$ in the same season at Tundun-wada while the least level of $2.20 \mathrm{mg} /$ $\mathrm{Kg}$ was recorded at Unguwa-fulani sampling site. High levels of nitrate ions during harmattan and dry seasons could be traced to excessive application of manure/fertilizers coupled with uses of wastewater as suggested by Adetunji et al. (2001) and Akan et al. (2008). Other sites with high concentrations of nitrate were; Sabon-gari (13.90 mg/Kg), Tundun-wada (11.40 $\mathrm{mg} / \mathrm{Kg}$ ) and $10.74 \mathrm{mg} / \mathrm{Kg}$ at Industrial-area along Jos road, all these results were obtained in rainy season. Nitrate concentrations were almost the same during rainy season 2013 (10.74$13.90 \mathrm{mg} / \mathrm{Kg}$ ) across the sampling sites as indicated in Figure 2. In this period, highest level was found at Sabon-gari (13.90 $\mathrm{mg} / \mathrm{Kg}$ ) while the least concentration of $10.74 \mathrm{mg} / \mathrm{Kg}$ was obtained at Industrial area along Jos road. Nitrate had concentrations in the range of 7.27-29.57 $\mathrm{mg} / \mathrm{Kg}$ for the year 2014 . Kwangila $(29.57 \mathrm{mg} / \mathrm{Kg})$ showed highest level during dry season followed by $26.93 \mathrm{mg} / \mathrm{Kg}$ at both Industrial-area along Jos road and Kwangila sampling sites during harmattan season and this was closely followed by Sabon-gari $(26.20 \mathrm{mg} / \mathrm{Kg})$ in the rainy season while the least concentration of $7.27 \mathrm{mg} / \mathrm{Kg}$ during harmattan season was found at Sabon-gari. Elevated levels of nitrate in soil during harmattan and dry seasons could be attributed to excessive application of nitrogenous fertilizers coupled with use of wastewater as suggested by Uwah et al. (2007). Other sampling sites with high concentrations of 


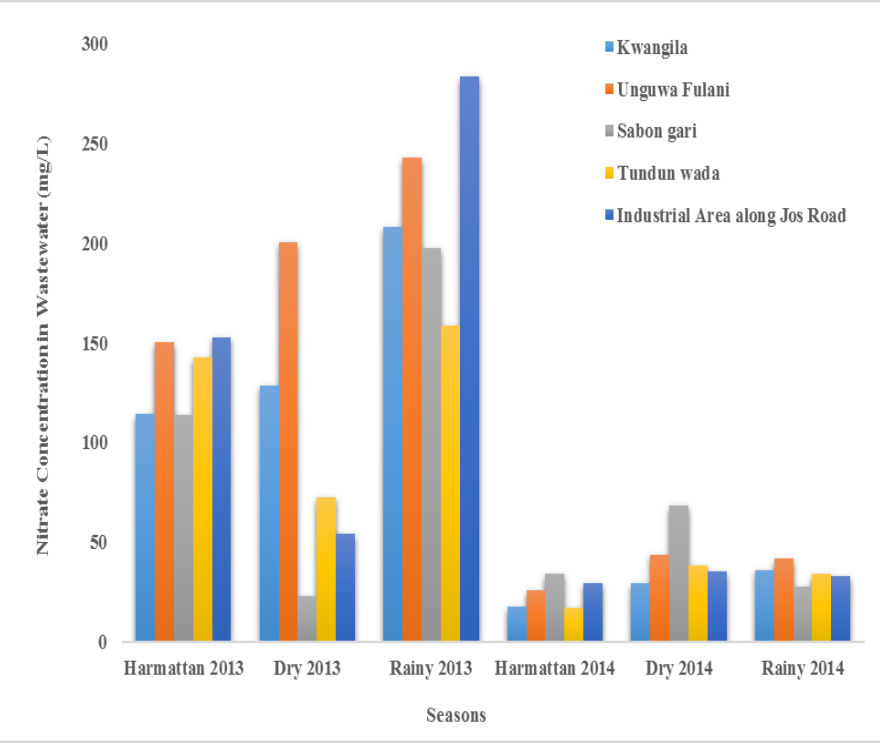

Figure 1. Nitrate concentrations in wastewater from Kubanni Stream Channels, Zaria.

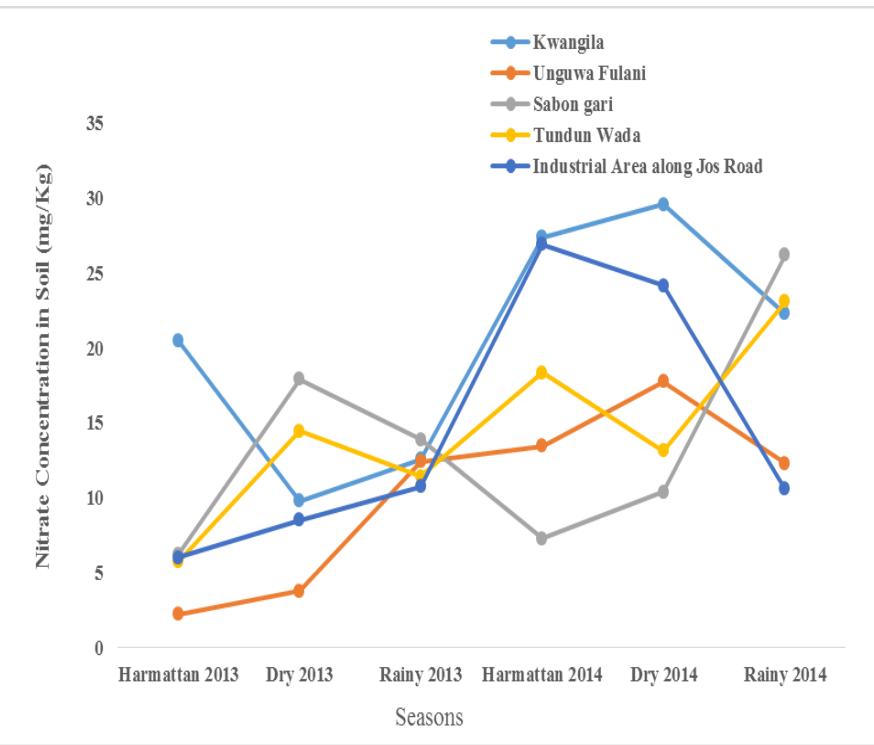

Figure 2. Nitrate concentrations in soil from Kubanni Stream Channels, Zaria.

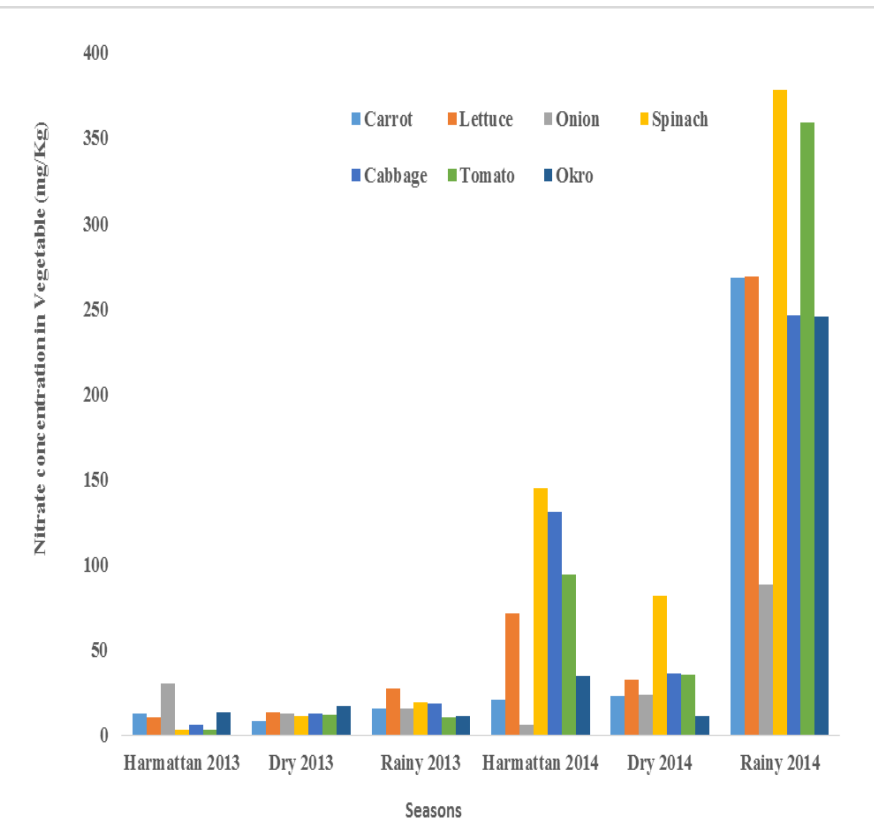

Figure 3. Nitrate concentrations in vegetables from Kubanni stream channels, Zaria. nitrate were; Industrial-area along Jos road $(24.17 \mathrm{mg} / \mathrm{Kg})$ in the dry season, $23.10 \mathrm{mg} / \mathrm{Kg}$ at both Kwangila and Tundunwada sampling sites in the rainy season, $18.37 \mathrm{mg} / \mathrm{Kg}$ during the harmattan season at Tundun-wada and Unguwa-fulani sampling site $(17.75 \mathrm{mg} / \mathrm{Kg})$ during the dry season. The chart revealed high levels of nitrate in 2014 and this could be related to flooding of 2013, this necessitated the application of more nitrogenous fertilizers than usual in the following year as suggested by Uwah et al. (2007). Comparing the results obtained in 2013 with that of 2014, it was revealed that in harmattan season 2013, the results indicated lower level of nitrate $(2.20-20.50 \mathrm{mg} / \mathrm{Kg})$ than harmattan season of 2014 $(7.27-26.93 \mathrm{mg} / \mathrm{Kg})$. Likewise, dry season 2013 (3.75-17.90 $\mathrm{mg} / \mathrm{Kg}$ ) showed low concentration of nitrate compared to dry season of $2014(10.40-29.57 \mathrm{mg} / \mathrm{Kg})$. In the same way, rainy season 2013 had lower concentration of nitrate ion in soil $(10.74-13.90 \mathrm{mg} / \mathrm{Kg})$ than rainy season of $2014(10.60-26.20$ $\mathrm{mg} / \mathrm{Kg}$ ). From the ANOVA Table 3 above, $\mathrm{P}=0.240>0.050$ shows there is no significant difference in nitrate levels across the sampling sites. The sampling locations revealed these statistical analysis as thus; Kwangila (20.357 \pm 7.879$)$, Unguwa -fulani (10.305 \pm 6.037$)$, Sabon-gari (13.645 \pm 7.515$)$, Tundunwada $(14.362 \pm 5.961)$ and Industrial-area along Jos road

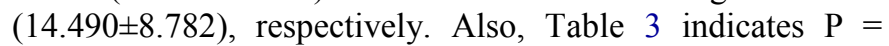
$0.802>0.050$ this means that there is no significant difference in nitrate concentrations across the seasons. The results showed that; harmattan season 2013 (16.138 7 7.858), dry season 2013 (16.146 \pm 9.673$)$, rainy season $2013(14.652 \pm 8.872)$,

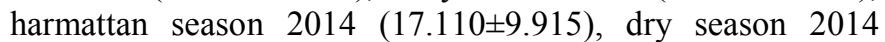

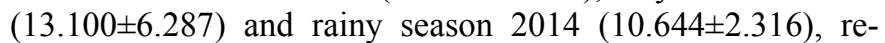
spectively. Some of these values are close to one another and may be attributed to anthropogenic activites in the sampling sites as suggested by Butu (2013). Table 4 shows Pearson Product Moment Correlation for nitrate levels in soil between the year 2013 and 2014. Statistical data showed the level of nitrate to be $10.401 \pm 5.150$ in 2013 while $18.863 \pm 7.300$ was obtained in 2014 with the degree of freedom $(\mathrm{df})=13$, Pearson correlation $(r)=0.137$ and $p=0.627>0.050$ indicates that there is negligible relationship between nitrate levels in soil for year 2013 to that of year 2014.

Nitrate concentrations in vegetables obtained along Kubanni stream channels is presented in Figure 3. The concentrations determined were in the range of $4.00-29.98 \mathrm{mg} / \mathrm{Kg}$ for the year 2013. Highest level of $29.98 \mathrm{mg} / \mathrm{Kg}$ was found during harmattan season in onion followed by $27.54 \mathrm{mg} / \mathrm{Kg}$ in lettuce during the rainy season and closely followed by $19.24 \mathrm{mg} / \mathrm{Kg}$ in spinach planted during the same rainy season while the least concentration of $4.00 \mathrm{mg} / \mathrm{Kg}$ was obtained in tomato cultivated in the harmattan season. Other vegetables with moderate levels of nitrate were; cabbage $(18.27 \mathrm{mg} / \mathrm{Kg})$ in the rainy season, okra $(17.24 \mathrm{mg} / \mathrm{Kg})$ during dry season, onion $(15.42 \mathrm{mg} / \mathrm{Kg})$ in the rainy season, lettuce $(13.45 \mathrm{mg} / \mathrm{Kg})$ in the dry season and carrot $(12.50 \mathrm{mg} / \mathrm{Kg})$ during harmattan season. Low levels of nitrate were recorded in 2013 which could be attributed to low absorption of nitrate by vegetables as a result of high anion exchange capacity of the soil hindrance its availability to plants as suggested by Shin-shou et al. (2003). In the year 2014, concentrations obtained were in the range of $5.74-378.40 \mathrm{mg} / \mathrm{Kg}$. Highest level of 378.40 $\mathrm{mg} / \mathrm{Kg}$ was found in spinach followed by tomato $(359.04 \mathrm{mg} /$ $\mathrm{Kg}$ ) and closely followed by both lettuce and carrot with concentration of $268.50 \mathrm{mg} / \mathrm{Kg}$, all these results were obtained in the rainy season whereas the least level of $5.74 \mathrm{mg} / \mathrm{Kg}$ was obtained in onion cultivated during harmattan season. Elevated levels of nitrate during rainy season could be as a 
result of excessive application of nitrogenous manure and fertilizers as suggested by Uwah et al. (2007). Other vegetables with high concentrations of nitrate were; cabbage $(246.00$ $\mathrm{mg} / \mathrm{Kg})$ and okra $(245.45 \mathrm{mg} / \mathrm{Kg})$ both in the rainy season, spinach $(144.90 \mathrm{mg} / \mathrm{Kg})$, cabbage $(131.10 \mathrm{mg} / \mathrm{Kg})$ and tomato $(94.20 \mathrm{mg} / \mathrm{Kg})$ all in the harmattan season. Comparing the results obtained for nitrate levels in vegetables between 2013 and 2014, it was revealed that in harmattan season 2014, the results indicated higher levels of nitrate $(5.74-144.90 \mathrm{mg} / \mathrm{Kg})$ than harmattan season of 2013 (4.00-29.98 mg/Kg). Likewise, dry season $2014(10.80-81.80 \mathrm{mg} / \mathrm{Kg})$ showed high level of nitrate in vegetable than dry season $2013(7.98-17.24 \mathrm{mg} / \mathrm{Kg})$. In the same way, rainy season $2014(88.00-378.40 \mathrm{mg} / \mathrm{Kg})$ had high level of nitrate than rainy season 2013 (11.34-27.54 $\mathrm{mg} / \mathrm{Kg}$ ). Elevated levels of nitrate recorded in 2014 might be connected to excessive application of nitrogenous fertilizers coupled with nitrogen-fixation effects by Nitrobacter bacteria as suggested by ATSDR (2011). The results obtained in this study were below maximum contaminant levels for nitrate in vegetables as recommended by European Commission $(3,100$ $\mathrm{mg} / \mathrm{Kg} /$ day). Nitrate levels reported by various workers in vegetables including; Akan et al., 2010 (177.89 - 674.22 mg/ $\mathrm{Kg}$ ) and Uwah et al., 2007 (27.78-904.60 mg/Kg) which were above the results obtained in the present study. Table 5 presents Analysis of Variance for nitrate in vegetables and shows $\mathrm{P}=0.946>0.050$ this means that there is no significant difference in nitrate levels among various vegetables analyzed. Their mean Nitrate levels and standard deviation revealed these; carrot $(52.332 \pm 106.172)$, lettuce $(62.572 \pm 104.658)$, onion (19.962 \pm 34.488$)$, spinach $(102.263 \pm 147.072)$, cabbage $(69.013 \pm 100.429)$, tomato $(81.748 \pm 140.657)$ and okra $(88.950 \pm 194.032)$, respectively. ANOVA Table 5 also shows $\mathrm{P}=0.924>0.050$ this means that there is no significant difference in nitrate concentrations across the seasons. The mean with standard deviation showed these; harmattan season 2013 (62.914 \pm 104.836$)$, dry season 2013 (43.587 \pm 55.274$)$, rainy season 2013 (73.194 \pm 138.965$)$, harmattan season 2014 (48.764 \pm 88.255$)$, dry season $2014(66.824 \pm 131.276)$ and rainy season $2014(113.436 \pm 190.292)$, respectively. In addition, Table 5 indicates $\mathrm{P}=0.003<0.050$ this means that there is significant difference in nitrate concentrations for wastewater, soil and vegetables of the sampling sites. Their mean and standard deviation elaborate these; wastewater $(91.783 \pm 76.765)$, soil $(14.632 \pm 7.551)$ and vegetable $(68.120 \pm 119.871)$, respectively. This means that nitrate levels differ significantly among wastewater, soil and vegetables of sampling sites as revealed from their mean. Table 6 presents summary of PPMC to establish the relationship between nitrate levels in vegetables for the year 2013 and 2014. Statistical analysis showed that the mean with standard deviation for nitrate level to be $1.102 \pm 1.079$ in 2013 while $135.140 \pm 141.503$ was obtained in 2014. Statistical analysis also showed Pearson correlation $(r)=-0.217$, degree of free$\operatorname{dom}(\mathrm{df})=19$ and $\mathrm{p}=0.344>0.050$ this means that there is negative relationship between nitrate levels in vegetables for the year 2013 and 2014, respectively.

Table 1. Analysis of variance (ANOVA) for nitrate in wastewater.

\begin{tabular}{|c|c|c|c|c|c|c|}
\hline Analysis of Variance & & Sum of Square & df & Mean Square & $\mathbf{F}$ & Significance \\
\hline $\begin{array}{l}\text { Nitrate in wastewater } \\
\text { (Locations) }\end{array}$ & $\begin{array}{l}\text { Between groups } \\
\text { Within groups } \\
\text { Total }\end{array}$ & $\begin{array}{r}6792.599 \\
164102.230 \\
170894.829\end{array}$ & $\begin{array}{r}4 \\
25 \\
29\end{array}$ & $\begin{array}{l}1698.150 \\
6564.089\end{array}$ & 0.259 & 0.902 \\
\hline $\begin{array}{l}\text { Nitrate in wastewater } \\
\text { (Seasons) }\end{array}$ & $\begin{array}{l}\text { Between groups } \\
\text { Within groups } \\
\text { Total }\end{array}$ & $\begin{array}{r}10526.914 \\
160367.915 \\
170894.829\end{array}$ & $\begin{array}{c}5 \\
24 \\
29\end{array}$ & $\begin{array}{l}2105.383 \\
6681.996\end{array}$ & 0.315 & 0.899 \\
\hline
\end{tabular}

Table 2. Summary of Pearson Product Moment correlation for nitrate in wastewater.

\begin{tabular}{ccccccc}
\hline Variables & $\boldsymbol{N}$ & $\overline{\boldsymbol{x}}$ & SD & r & df & Significance \\
\hline Nitrate 2013 & 15 & 149.457 & 70.238 & -0.263 & 13 & 0.343 \\
Nitrate 2014 & 15 & 34.109 & 12.071 & & \\
\hline
\end{tabular}

Table 3. Analysis of variance (ANOVA) for nitrate in soil.

\begin{tabular}{|c|c|c|c|c|c|c|}
\hline Analysis of Variance & & Sum of Square & df & Mean Square & $\mathbf{F}$ & Significance \\
\hline $\begin{array}{l}\text { Nitrate in soil } \\
\text { (Locations) }\end{array}$ & $\begin{array}{c}\text { Between groups } \\
\text { Within groups } \\
\text { Total }\end{array}$ & $\begin{array}{c}315.373 \\
1338.293 \\
1653.666\end{array}$ & $\begin{array}{c}4 \\
25 \\
29\end{array}$ & $\begin{array}{l}78.843 \\
53.532\end{array}$ & 1.473 & 0.240 \\
\hline $\begin{array}{l}\text { Nitrate in Soil } \\
\text { (Seasons) }\end{array}$ & $\begin{array}{c}\text { Between groups } \\
\text { Within groups } \\
\text { Total }\end{array}$ & $\begin{array}{c}144.761 \\
1508.904 \\
1653.666\end{array}$ & $\begin{array}{c}4 \\
25 \\
29\end{array}$ & $\begin{array}{l}28.952 \\
62.871\end{array}$ & 0.461 & 0.802 \\
\hline
\end{tabular}

Table 4. Summary of Pearson Product Moment correlation for nitrate in soil.

\begin{tabular}{ccccccc}
\hline Variables & $\boldsymbol{N}$ & $\overline{\boldsymbol{x}}$ & SD & r & df & Significance \\
\hline Nitrate 2013 & 15 & 10.401 & 5.150 & 0.137 & 13 & 0.627 \\
Nitrate 2014 & 15 & 18.863 & 7.300 & & & \\
\hline
\end{tabular}


Table 5. Analysis of variance (ANOVA) for nitrate in vegetables.

\begin{tabular}{|c|c|c|c|c|c|c|}
\hline Analysis of Variance & & Sum of Square & $\overline{\text { df }}$ & Mean Square & $\mathbf{F}$ & Significance \\
\hline $\begin{array}{l}\text { Nitrate in vegetable } \\
\text { (Among various vegetable) }\end{array}$ & $\begin{array}{l}\text { Between groups } \\
\text { Within groups } \\
\text { Total }\end{array}$ & $\begin{array}{c}26312.797 \\
562822.011 \\
589134.808\end{array}$ & $\begin{array}{r}6 \\
35 \\
41\end{array}$ & $\begin{array}{l}4385.466 \\
16080.629\end{array}$ & 0.273 & 0.946 \\
\hline $\begin{array}{l}\text { Nitrate in vegetable } \\
\text { (Seasons) }\end{array}$ & $\begin{array}{c}\text { Between groups } \\
\text { Within groups } \\
\text { Total }\end{array}$ & $\begin{array}{c}21591.818 \\
567542.990 \\
589134.808\end{array}$ & $\begin{array}{c}5 \\
36 \\
41\end{array}$ & $\begin{array}{c}4318.364 \\
15765.083\end{array}$ & 0.274 & 0.924 \\
\hline $\begin{array}{l}\text { Nitrate among } \\
\text { wastewater, soil and } \\
\text { vegetables }\end{array}$ & $\begin{array}{l}\text { Between groups } \\
\text { Within groups } \\
\text { Total }\end{array}$ & $\begin{array}{l}94779.206 \\
761683.302 \\
856462.509\end{array}$ & $\begin{array}{c}2 \\
99 \\
101\end{array}$ & $\begin{array}{c}47389.603 \\
7693.771\end{array}$ & 6.159 & 0.003 \\
\hline
\end{tabular}

Table 6. Summary of Pearson Product Moment correlation for nitrate in vegetable.

\begin{tabular}{lcccccc}
\hline Variables & $\boldsymbol{N}$ & $\overline{\boldsymbol{x}}$ & SD & r & df & Significance \\
\hline Nitrate 2013 & 21 & 1.102 & 1.079 & -0.217 & 19 & 0.344 \\
Nitrate 2014 & 21 & 135.140 & 141.503 & & & \\
\hline
\end{tabular}

\section{Conclusions}

The present study concluded that diverse nitrate levels in wastewater were in the range of $23.05-283.54 \mathrm{mg} / \mathrm{L}$ for the year 2013 and $16.85-68.05 \mathrm{mg} / \mathrm{L}$ in the year 2014; soil had concentrations in the range of $2.20-20.50 \mathrm{mg} / \mathrm{kg}$ for 2013 and $7.27-29.57 \mathrm{mg} / \mathrm{kg}$ for the second year while the vegetable had concentrations in the range of $3.80-23.65 \mathrm{mg} / \mathrm{Kg}$ for the year 2013 and $7.48-27.15 \mathrm{mg} / \mathrm{Kg}$ in year 2014. The contamination of the stream affects the vegetables that are irrigated with the water of the stream. This may interfere with food chain and affect the human consumers of these vegetables. Therefore, higher nitrate levels in carrot, lettuce, onion, spinach, cabbage, tomato and okra were recorded grown along with the Kubanni River during both the years. Analysis of variance (ANOVA) for wastewater, soil and vegetables across the locations and seasons revealed no significant difference in the samples analyzed and this was due to sampling sites were within the same vicinity therefore they experienced similar level of contamination, similar geological soil formation and similar anthropogenic activities. There is a need to create a comprehensive health education plan to communicate appropriate public health awareness to the farmers and the community through mass media on the implication of unhygienic environment and health implications of using wastewater and excessive application of chemicals on farmlands.

Open Access: This is open access article distributed under the terms of the Creative Commons Attribution License, which permits unrestricted use, distribution, and reproduction in any medium, provided the original author(s) and the source are credited.

\section{REFERENCES}

Ademoroti, C.M.A. (1996).Standard method for water and effluents analysis. Foludex Press Ltd., Ibadan. 3: 28-118.

Adetunji, M.T., Martins, O. and Arowolo, T.A (2001). Seasonal variation in atmospheric deposition of nitrate, sulphate, lead, zinc and copper in south western Nigeria. Communication of Soil Science and Plant Analysis, 32(1-2): 65-73, DOI 10.1081/ CSS-100102993.

ATSDR, Agency for Toxic Substance and Disease Registry (2011). Nitrate and nitrites. CAS 84145-82-4, 14797-65-0. U.S. Department of Health and H man Services. Public Health Services Unit. Retrieved from http://www.atsdr.cdc.gov/toxfaq.html_on $25^{\text {th }}$ October, 2013.

Agusa, T., Kunito, T., Fujihara, J. and Kubota, R. (2006).Water manganese exposure and children's intellectual function.
Environmental Pollution, 139: 95-106.

Akan, J.C., Abdulrahman, F.I., Sodipo, O.A. and Lange, A.G. (2010).Physicochemical parameters in soil and vegetable samples from Gongulon agricultural site, Maiduguri, Borno State, Nigeria. Journal of American Science, 6: 78-87.

Akan, J.C., Abdulrahman, F.I., Dimari, G.A. and Ogugbuaja, V.O. (2008). Physicochemical determination of pollutants in wastewater and vegetable samples along Jakara Wastewater Channel in Kano Metropolis, Kano State, Nigeria. European Journal of Scientific Research, 23: 122-133.

APHA, American Public Health Association (2012). Standard Methods for the Examination of Water and Wastewater, $22^{\text {th }}$ Edition, Washington, DC pp: 1360.

Anjana, S., Umar, M., Igbal, B. and Abrol, Y.P. (2006). Are nitrate concentrations in leafy vegetables within safe limits? Proceedings of the workshop on nitrogen in environment, industry and agriculture, New Delhi, India. pp: 81- 84.

Berman, E. (1980). Toxic Metals and their Analysis. $4^{\text {th }}$ Edition, Longman Publishers London. pp: 82- 87.

Butu, A.W. (2013). Concentration of metal pollutants in river Kubanni, Zaria, Nigeria. Journal of Natural Sciences Research, 3: 19- 25.

Farooq, M.., Anwar, F. and Rashid, U. (2008). Appraisal of heavy metals grown in the vicinity of an industrial area. Pakistan Journal of Botany, 40: 2099-2106.

Grubben, G.J.H. (1976).The cultivation of Amaranthus as a tropical leaf vegetable with special reference to southern Dahomey. Res. Royal Tropical Institute, Netherlands. pp: 6

Ikemoto, Y., Teraguchi, M. and Kogayashi, Y. (2002). Plasma Level of Nitrate in Congenital Heart Disease: Comparison with Healthy Children. Pediatric Cardiology, 23: 132-136.

Ishiwata, H., Yamada, T., Yoshiike, N., Nishijima, M., Kawamoto, A. and Uyama, Y. (2002). Daily intake of food addictive in Japan in five age groups estimated by the market basket method. European Food Research and Technology, 215: 367- 374.

Jameel, A.A. and Sirajudeen, I. (2006). Risk assessment of physiochemical contaminants in groundwater of Pettavaaithalai area, Tiruchirappalli Tamilnadu, India. Environmental Monitoring and Assessment, 123: 299- 312

Kenneth, H. (1990). Official Methods of Analysis of AOAC, $5^{\text {th }}$ Edition, AOAC Inc. Arlington, USA, pp: 56-58, 234.

Kumar V., Srivastava, S. Chauhan, R.K., Thakur, R.K. and Singh, J. (2017). Heavy metals and microbial contamination of certain leafy vegetables grown in abattoir effluent disposal province of Saharanpur (Uttar Pradesh), India. Archives of Agriculture and Environmental Science, 2(1): 36-43.

McCall, D. and Willumsen, J. (1998). Effects of nitrate, ammonium and chloride application on the yield and nitrate content of soil-grown lettuce. Journal of Horticulture Science and Biotechnology, 73: 698-703.

Morrison, R., Robinson, R.K. and Sadler, M.J. (2001). Encyclopedia of food science, food technology and nutrition, vegetables of 
temperate climates. Academic Press, New-York. pp: 78- 93

Musa, A.S., Elferjani, H.S., Haroun, F.A. and Abdelnabi, F.F. (2009). Determination of available nitrate, phosphate and sulphate in soil samples. International Journal of Pharm. Tech. Research, 3: 598-604.

Munson, R.D. and Nelson, W.L. (1990). Principle and practices in plants analysis in "soil testing and plant analysis" (ed) Westernan, R.L.; Mandison, SSSA, pp: 359-387.

Nathan D.M., Siegel A.J. and Bunn H.F. (1977). "Acute methemoglobinemia and hemolytic anemia with phenazopyridine". Archives of Internal Medicine,137(11):1636-1638.

Oladeji, S.O. (2017). Evaluation of nickel levels in wastewater, soil and vegetable samples grown along Kubanni stream channels in Zaria, Kaduna State, Nigeria. Archives of Agriculture and Environmental Science, 2(3): 141-147.

Radojevic, M. and Bashkin, V.N. (1999). Practical Environmental Analysis. The Royal Society of Chemistry, Cambridge, UK, pp:
466-475.

Reddy, K.S. and Menary, R.C. (1990). Nitrate reductase and nitrate accumulation in relation to nitrate toxicity in Boronia megastigma. Physiology Plantarum, 78: 430-434.

Robert, J. (1992). Elementary Statistics. $6^{\text {th }}$ Edition, PWS Publishers, Wadsworth Inc., USA. pp: 120-140.

Shin-Shou, C., Jen-Chien, C. and Hwang, D. (2003). A High Performance Liquid Chromatography Method for Determining Nitrate and Nitrite Levels in Vegetables. Journal Food and Drug Analysis, 11: 233-238.

Tchobanoglous, D., Lipworth, L., Petridou, E. and Adam, H. (2003). Epidemiology of Cancer. In: Cancer, Principles and Practice of Oncology, DeVita, V.T., Hellman, S. and Rosenberg, S.A. (Eds.) Lippincott Company, Philadelphia, pp: 231-258.

Uwah, E.I., Akan, J.C., Moses, E.A., Abah, J. and Ogugbuaja, V.O. (2007). Some anions levels in fresh vegetables in Maiduguri, Borno State, Nigeria. Agricultural Journal, 2: 392-39. 